\title{
DETERMINING THE COMPETITIVENESS LEVEL AND \\ COMPETITIVITY FACTORS OF THE THERMAL HEALTH TOURISM SECTOR OF SOUTH EGEAN THERMAL TOURISM DEVELOPMENT REGION
}

Murat BAYAT 1

Fuat YALMAN 2
Received Date (Başvuru Tarihi):

Accepted Date (Kabul Tarihi):

Published Date (Yayın Tarihi):
$14 / 09 / 2020$

$10 / 10 / 2020$

$10 / 12 / 2020$

In the article, the first author is in the role of the Corresponding Author.

\section{ABSTRACT}

Keywords:

Thermal Health Tourism,

Competitiveness,

South Aegean Thermal Tourism Development Region

JEL Codes:

I11, M31, M30
The purpose of this study is to determine the competitiveness level and competitiveness factors of the thermal health tourism sector of the South Aegean Thermal Tourism Development Region (İmir, Manisa, Aydin and Denizli). Initially, the competitiveness levels of the thermal health tourism sector of the region were determined, and then the sub-variables of the competitive factors of the thermal health tourism sector were defined. Finally, suggestions were proposed to improve this level of competitiveness. The population of the research is the medium and senior managers of thermal health tourism facilities operating in Izmir, Manisa, Aydin and Denizli provinces. The quantitative research method was used in the study, and the data was collected from 400 managers using face-toface survey technique. The data were interpreted through SPSS and AMOS package programs, using the techniques of frequency analysis, descriptive statistics, explanatory factor analysis (EFA) and confirmatory factor analysis (CFA). According to the results of the research, the level of competitiveness of the Thermal Health Tourism Sector of the South Aegean Thermal Tourism Development Region was determined at a medium level as a result of the analysis made with the diamond model. This result was achieved by taking into account the four main variables examined and the level of state contribution to the sector's competitiveness. The confirmatory factor analyses are performed; It has been determined that the thermal health tourism sector has an acceptable fit index for competitiveness factors. In the reliability analysis for the variables of the study, it was determined that the scales have high-reliability levels.

\footnotetext{
${ }^{1}$ Assist Prof. Dr., Duzce University, Faculty of Business, muratbayat@duzce.edu.tr,

${ }^{2}$ Assist Prof. Dr., Duzce University, Faculty of Business, fuatyalman@duzce.edu.tr,

https:// orcid.org/0000-0003-0029-948X

https://orcid.org/0000-0002-1041-1837
} 


\section{GÜNEY EGE TERMAL TURİM GELISŞIM BÖLGESINIIN TERMAL SAĞLIK TURIZMİ SEKTÖRÜNÜN REKABETÇILIKK DÜZEYINİN VE REKABETÇILIIK FAKTÖRLERININ TESPITT EDILMESİ}

$\ddot{O Z Z}$

\section{Anahtar Kelimeler:}

Termal Sağlık Turizmi,

Rekabetçilik,

Güney Ege Termal Turizm

Gelişim Bölgesi

\section{JEL Kodlari:}

I11

M312

M30
Bu çalışmanın amacl; Güney Ege Termal Turizm Gelişim Bölgesinin (İzmir, Manisa, Aydın ve Denizli) termal sağlık turizmi sektörünün rekabetçilik düzeyinin ve rekabetçilik faktörlerinin tespit edilmesidir. Öncelikle bölgenin termal sağllk turizmi sektörünün rekabetçilik düzeyleri tespit edilmiş, daha sonra termal sağlık turizmi sektörünün rekabetçilik faktörlerinin alt değişkenleri tanımlanmıştır. Nihayetinde ise bu rekabetçilik düzeyinin geliştirilmesi için önerilerde bulunulmuştur. Araştırmanın ana kütlesini İzmir, Manisa, Aydın ve Denizli illerinde faaliyet gösteren termal sağglk turizmi tesislerinin orta ve üst düzey yöneticileri oluşturmaktadır. Nicel araştırma yönteminin kullanıldı̆̆̆ araştırmada, veriler yüz yüze anket tekniği ile 400 yöneticiden toplanmıştır. Veriler SPSS ve AMOS paket programlan aractlığıyla ile frekans analizleri, betimleyici istatistikler, açıklayıcı faktör analizi (AFA) ve doğrulayıcı faktör analizi (DFA) teknikleri kullanılarak yorumlanmıştır. Araştırmanın sonuçlarına göre; Güney Ege Termal Turizm Gelişim Bölgesinin Termal Sağllk Turizmi Sektörünün rekabetçilik seviyesi, elmas modeli ile yapilan analiz sonucu, orta seviyede tespit edilmiştir. Bu sonuca, incelenen dört ana değişken ve devletin sektörün rekabetçilik düzeyine yaptığı katkı düzeyleri dikkate alınarak ulaşılmıştır. Doğrulayıcı faktör analizleri yapılarak; termal sağlık turizmi sektörü rekabetçilik faktörlerin kabul edilebilir uyum indeksine sahip olduğu tespit edilmiştir. Araştırmanın değişkenleri için yapılan güvenilirlik analizinde, ölçeklerin yüksek güvenilirlik derecelerine sahip olduğu tespit edilmiştir. 


\section{INTRODUCTION}

In the world tourism market, which has reached an absolute saturation against the standard tourism service offered by mass tourism, the demand for new alternative tourism types has increased rapidly. Besides, the increase in the quality of life and the rapid ageing of the world population and increasing medical treatment costs have led people to seek other treatment methods as a result of the increasing welfare level worldwide. Our country, which has been following the development of tourism in a planned way and has taken a specific route from the past, has the potential to respond to such demand changes and strengthen its position in the market. For this reason, thermal health tourism, which is one of the essential alternative tourism types as emphasized in tourism policies, is an essential alternative in ensuring tourism diversity in our country, spreading tourism and tourism activities throughout the country (Albayrak, 2013).

Thermal health tourism is a tourism activity aimed at relocating people for their health, recreation and entertainment (Timur, 2015). Thermal tourism is one of the most important types of health tourism and constitutes the basis of health tourism (Giritlioğlu, 2012: 16). Thermal tourism is a type of tourism that takes place in regions where healing waters are containing beneficial minerals and healing mud and vapours that naturally rise above the ground at a specific temperature (Ilban et al., 2008: 106). Thermal facilities are the organizations that generate income by trying to be beneficial to people with the thermal products and services they contain. In the globalizing world, the rapidly growing thermal health tourism sector has emerged as a concept that includes both treatment and holiday elements as a result of dynamics such as problems in the provision of health services and awareness of consumers (Erdinç, 1991).

Our country has rich underground resources in terms of thermal health tourism potential. Besides being primarily for therapeutic purposes; thermal resources are also used in order to relax, play sports, stress, spend leisure time and have fun. The effective use and evaluation of these resources are crucial for the national economy and providing a competitive advantage. However, although our country has vibrant 
geothermal potential and high healing thermal water resources; a competitive environment could not be created with European countries due to the insufficient number of centres in terms of quality and quality of centres that provide the cure park, cure centre and accommodation facility integrity and the lack of thermal city destinations with thermal facilities at international standards. Therefore, it is essential to gain strength and competitiveness in order to increase Turkey's share in the growing health tourism pie worldwide (Ministry of Health, 2012).

The purpose of this research is to determine the competitiveness level and competitiveness factors of the thermal health tourism sector of the South Aegean Thermal Tourism Development Region (İzmir, Manisa, Aydın and Denizli). In this context, first of all, the competitiveness levels of the thermal health tourism sector of the region were determined, and then sub-variables of the competitive factors of the thermal health tourism sector were defined. Finally, suggestions were made to improve this level of competitiveness. There has not been found any extensive research on the subject of Turkey, even though the subject of the research had been discussed in detail in the international literature. The study evaluates the scales accepted with their high reliability and validity prepared for different cultures and sectors from the perspective of a new culture (Turkish) and sector (service-thermal health tourism) and contributes with confirming information to the literature.

\section{LITERATURE SURVEY}

\subsection{General Situation of Thermal Health Tourism Sector}

Health tourism, which has an important place in the tourism sector in recent years and is considered as one of the alternative tourism types. Many countries have made substantial progress in the field of health tourism, and the health tourism sector has provided important resources and employment areas to these progressing countries as well as the people involved in this field (Rosensweig, 2007). Thermal health tourism, which is one of the health tourism types, is defined as the understanding of the importance of thermal waters and going to established in thermal centres as a result of treating people's lost health conditions, ensuring healthy people to stay healthier and extending their lifespan in this way (Usta, 2002: 59; Timur, 2015: 
4). It is a concept intertwined with tourism. Thermal health tourism is one of the most important types of health tourism and forms the basis of health tourism (Giritlioğlu, 2012: 16).

Turkey, which has hosted the rich history and has various civilizations in terms of geothermal resource richness and potential, it ranks seventh in the world scale, fifth in terms of direct use and first in Europe (Ministry of Health, 2012: 118). The history of the use of hot springs for health and treatment purposes on the territory of our country is a tradition that goes back a thousand years ago and continues (Karagülle and Doğan, 2002: 1). As a result, Turkey can use only a fraction of $3 \%$ of the geothermal potential, which is thought to be 31,500 megawatts thermal. This potential means 5 million households heating equivalent or over 1 million thermal bed capacity (Gawell \& Greenberg, 2007; Karamustafa et al., 2009: 497). The most important advantages of these thermal resources are naturally coming out, rich in minerals and rich in sulphur and mineralization.

In the rapid developments in thermal health tourism, which is a sub-element of health tourism worldwide, in recent years; factors such as the increasing importance given to human health, the expectations of those participating in tourism change over time, the increase in the elderly population in Europe, the thermal tourism being applicable in all months of the year, the length of the treatment period in thermal tourism, and the desire of people to avoid chemical and artificial treatments (Çetin, 2011: 902). Although there are extensive studies on the competitiveness of health tourism in the literature, there is no framework to define international competitiveness. However, in this sense, as important determinants about the competitive position of a destination; destination image, climate and environment, charm, historical monuments, natural beaches, health tourism infrastructure, service quality, hospitality, accessibility, facilities and price can be enumerated in general (Upadhyay, 2011).

When looking at similar studies; in a study conducted by Sengul and Bulut (2019) in order to examine the SWOT analysis of thermal tourism in Turkey; it was stated and emphasized that in addition to good advertising and promotional activities, 
physical and chemical analyses of existing thermal resources should be made, scientific purposes should prepare medical bacteriological evaluation reports. Then, the facilities should be established following these reports by taking into consideration the importance of qualified workforce with quality products and services. Similarly, the competition conditions of the tourism sector in Antalya were evaluated within the framework of Porter's five power analysis, the factors affecting the structure of the current and future competition level were determined, and the reasons and results of the deficiencies in the competitive strategies of the enterprises were determined (Keklik Okul, 2019).

In another study, the thermal tourism potential of the district centre of Kozakl1 (Nevşehir) and the thoughts of tourists on thermal tourism was evaluated, and it was concluded that thermal tourism enterprises should provide accurate information to customers in promotional tools such as advertising brochures and catalogues and activities that would strengthen the image of the enterprise (Çetin, 2011). On the other hand, by using Porter's diamond model, Bulu and Eraslan (2008) analyzed the international competitiveness of the tourism sector in the province of Bolu. As a result of the mentioned study, it was determined that the international competitiveness of the tourism sector in Bolu province was at the medium level.

\subsection{Diamond Model Approach in Competitiveness Power Analysis}

Porter (1990: 71), in his development of the dynamic diamond model, revealed why a country has been prosperous in specific industries and why it has failed in others. According to Porter, countries achieve success in the industries and sectors where the national diamond is the most efficient and this success is achieved in the business clusters (Sayın, 2008: 58-59). Business clusters are the industrial regions where business organizations and various public and private sector organizations operate together. It will strengthen the pace of providing competitive advantages in countries and industries by developing and increasing the number of these clusters. In a study carried out to determine the competitiveness of the medical tourism industry of the East Azerbaijan region, it was emphasized that long-term planning and strengthening 
the tourism infrastructure of the private sector should be taken into the agenda in order to establish the medical tourism policy of the region (Momeni et al., 2017).

The frame drawn with the diamond model is applicable not only for countries but also for different regions and cities within the countries. The effects of local conditions and local business environments determined by diamond model and their role in determining competitive advantage have increased with globalization (Porter, 1998: 8). The diamond model analyses the elements of global competition within the framework of a systematic approach to reveal the determining elements of the national competitive advantage systematically.

In the diamond model, Porter (1990: 71) stated the factors that determine the competitiveness of countries as factor conditions, demand conditions, relevant and supportive industries and firm strategy, structure and competition conditions. In addition to the four key factors that determine competitiveness in diamond, Porter also mentions an indirect (exogenous) factor that affects diamond and thus is effective in changing the national competitive advantage (Wu et al., 2007). As a result, this external variable added later affects any of the internal variables, helping to achieve competitiveness. Figure 1 shows Porter's diamond model.

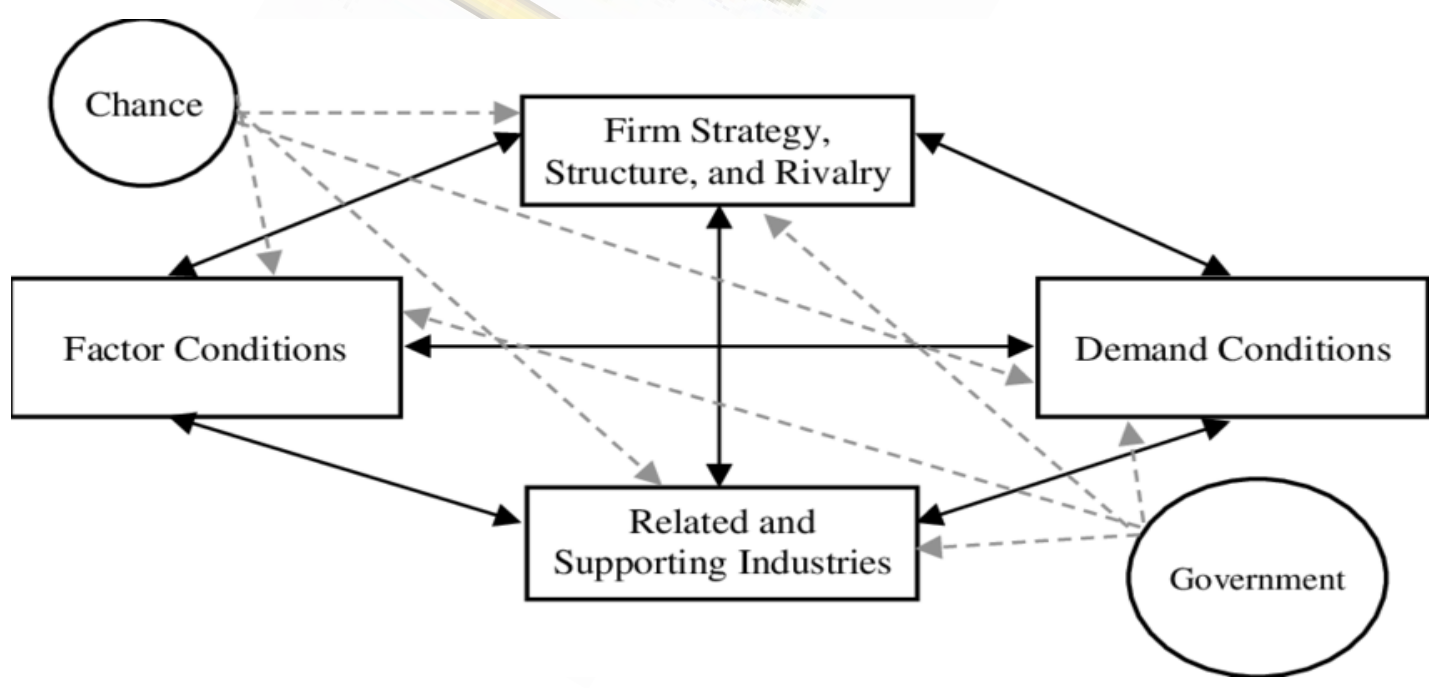

Figure 1. Porter's Diamond Model

Source: Porter, ME. E. The Competitive Advantage of Nations, New York, The Mcmillan Pres, 1990, p. 127.

Input (factor) conditions are the requirements of a company for its skilled workforce, natural resources, all kinds of infrastructure, equity and university research 
supports. The characteristics of the factor conditions differ according to the country or region (Webster \& Muller, 2000; Donald, 1993). Demand conditions include various variables and regulations related to the demand for a product in an industry/sector and affect competitiveness in this direction (Lall, 2001). Porter (1990: 86) emphasizes that there must first be an internal demand and a qualified local demand for a particular good or service in an industry. The existence of existing domestic demand and a qualified local demand for the leading sectors of the countries has a positive effect on the competitiveness of those sectors in the international arena. Porter sees the excessive number of supplier firms in an intensely competitive environment as a prerequisite for firms to have competitive power in export markets (Porter, 1990: 100). Porter, with its concept of relevant and supportive sectors in the diamond model, refers to the suppliers that provide the everyday use of the industry's existing opportunities and resources as well as the inputs the industry needs to make production (Alsaç, 2010). Firm strategy and competitive structure; express the methods of managing and competing firms, the goals that firms want to achieve, and the competitiveness in the relevant industry and the size of the national competition environment (Hodgetts, 1993).

In summary, Porter's diamond model has been accepted by many researchers as it offers a broad framework in explaining the competitive advantages of countries, combining competitive strategy and international economy (Grant, 1991: 117). The power of Porter's model lies under the scope of business-specific, industry-specific and country-specific factors. Porter, for the first time, added the concept of the industry to the model and integrated both micro and macro perspectives in a model (Cho, 1999: 32).

\section{METHODOLOGY OF THE RESEARCH}

\subsection{Research Method}

\subsection{Conceptual Model of the Research}

The conceptual model of the research was designed within the framework of defining the competitiveness level of the thermal health tourism sector and subvariables of competitiveness factors. 


\subsection{Research Unit, Universe and Sample}

The South Aegean Thermal Tourism Development Region (İzmir-ManisaAydin-Denizli), which was created by the stratified (clustering) sampling method within the scope of the 2007-2023 Thermal Tourism Master Action Plan of the Ministry of Culture and Tourism of the Ministry of Culture, was taken as the basis for the universe of the research. All top and middle-level managers of thermal and spa facilities with thermal health tourism operation certificate in these provinces have been accepted as research units. The questionnaire forms were distributed randomly to the upper and middle-level managers of the certified thermal and spa facilities in the selected provinces. In each of the provinces mentioned, 100 questionnaire forms were applied to the people working in upper and middle management positions. A total of 400 questionnaire forms were applied.

\subsection{Data Collection Method}

Questionnaire technique was used to obtain the data. For the preparation of the research questionnaire, a detailed literature review was conducted and in the light of the documents and information obtained, pre-developed (different or similar areas) model studies related to the variables in the research were selected for the preparation of the research questionnaire. They were harmonized with the structural features of the thermal health tourism sector that constitutes the subject of the research. A pilot application (pre-test) was performed on 30 thermal facility managers in order to ensure the structural validity of the research questionnaire. The results obtained in this direction revealed that the developed questionnaire was sufficient in terms of structural validity and content. The questionnaire form consists of three parts. In the first part, there are statements about competitiveness consisting of 45 propositions. In the second part, there is information about demographic features related to thermal facility managers. In the third part, there is contact information about the researcher.

\subsection{Scales Used in the Research}

On competitiveness, the 5-dimensional city and country competitiveness scale (Diamond Model) developed by M.E. Porter (1979) was used. At the same time, creating the scale; "The Competitive Advantage of Nations" by Porter (1979), "The 
Competitive Advantage of Nations: An Exposition of the Limitations of the Single Nation 'Diamond" Theory in the Case of Zimbabwe's Exports to the OECD and South Africa Markets" developed by Mapuranga (1999 and the studies named "Strategic Orientation of Business Enterprises: The Construct, Dimensionality and Measurement" by Venkatraman (1989) were used.

\subsection{Data Analysis Method}

The data collected within the scope of the research were uploaded and analyzed in SPSS and AMOS statistical analysis programs. The data were first analyzed for reliability, and then the demographic characteristics of the research were examined in terms of variance, mean, frequency distribution and proportionally. Confirmatory factor analysis (CFA) was performed with the AMOS software to reveal how latent variables can be explained in terms of observed variables.

\subsection{Data Set Analysis Criteria}

Descriptive factor analysis (DFA) and confirmatory factor analysis (CFA) were used in data analysis depending on the purpose of the research conducted and the data collection method.

\subsubsection{Criteria for Explanatory Factor Analysis}

The common factor variance was taken into account to examine the factor load values of the items before rotation. As the factoring technique, the analysis of the main components used in social sciences which are the easiest to interpret is used. In order to extract the variables that do not measure the same structure, the lower limit is accepted as 0.45 for the load values in the factor in which the variables are included. Items collected under more than one factor and where the difference between factor loads was less than 0.10 were defined as overlapping factors and removed from the scale. Factors with an original value above one were considered as important factors. $30 \%$ limit value is accepted as the announced variance rate Rotation was carried out in order to ensure the independence of the factors, clarity and significance in interpretation. Vertical rotation technique was used as rotation technique. 


\subsubsection{Criteria for Confirmatory (CFA) Factor Analysis}

Firstly, it was checked whether the standardized loading of observed variables was higher than 0.5 , then compound reliability (CR) and the average variance (AVE) tests were performed. For each structure, it was examined whether AVE is more significant than its variance shared with other structures. If the average variance determined for each structure is larger than the variance shared with the structures with other variables, the condition that distinguishes, validity is checked.

\section{FINDINGS OF THE RESEARCH}

\subsection{Normality Distribution of Research Data}

In the study, the standard distribution test, Kolmogorov-Smirnov normality test, was applied, and the data were not distributed normally. In extensive sample data ( $\mathrm{n}>400)$, the test does not have to result in normality requirement is not met. If the distribution shows a feature close to normal, it is not considered that the normality condition at p-value is not met (Şencan, 2005). Also, in cases where the number of samples/subjects included in the analysis is high, it is accepted that the variables provide the assumption of normality according to the central limit theorem (Smidt et al., 2001).

\subsection{Reliability of Research Data}

The reliability of the research data was analyzed by Cronbach's Alpha Coefficient method. Competitiveness factors that constitute the variables of the research were subjected to reliability analysis with 45 questions. Cronbach's Alpha Coefficient was found to be 0.939 . Therefore, the reliability of the research is very high.

\subsection{Demographic Findings}

Frequency distributions related to primary and demographic characteristics of thermal hotel managers are presented in Table 1. 
Table 1. Frequency Distributions Regarding Basic and Demographic Characteristics of Managers

\begin{tabular}{|c|c|c|c|c|c|c|}
\hline Gender & Frequency & Percent & & Education level & Frequency & Percent \\
\hline Male & 229 & 57.3 & & Primary school graduate & 19 & 4.8 \\
\hline Female & 171 & 42.8 & & Secondary School Graduate & 26 & 6.5 \\
\hline Total & 400 & 100.0 & & High school graduate & 128 & 32.0 \\
\hline Income status & Frequency & Percent & & Graduated from a University & 202 & 50.5 \\
\hline $0-2234 €$ & 14 & 3.5 & & Master / Doctorate & 25 & 6.3 \\
\hline $2235 €-3499 £$ & 18 & 4.5 & & Total & 400 & 100.0 \\
\hline $3500 €-4999 €$ & 23 & 5.8 & & Age & Frequency & Percent \\
\hline 5000 モ-6999 € & 166 & 41.5 & & $18-25$ & 74 & 18.5 \\
\hline 7000 €-9999 £ & 96 & 24.0 & & $26-35$ & 99 & 24.8 \\
\hline $\begin{array}{l}10000 € \text { and } \\
\text { Over }\end{array}$ & 83 & 20.8 & & $36-45$ & 129 & 32.3 \\
\hline Total & 400 & 100.0 & & $46-55$ & 72 & 18.0 \\
\hline $\begin{array}{l}\text { Position in } \\
\text { Business }\end{array}$ & Frequency & Percent & & 56 and over & 26 & 6.5 \\
\hline Senior manager & 88 & 22.0 & & Total & 400 & 100.0 \\
\hline $\begin{array}{l}\text { Mid-level } \\
\text { manager }\end{array}$ & 312 & 78.0 & & City of Residence & Frequency & Percent \\
\hline Total & 400 & 100.0 & & Izmir & 100 & 25.0 \\
\hline $\begin{array}{l}\text { Sec. Operation } \\
\text { time }\end{array}$ & Frequency & Percent & 3 & Aydin & 100 & 25.0 \\
\hline $1-5$ years & 150 & 37.5 & 5 & Denizli & 100 & 25.0 \\
\hline $6-10$ years & 67 & 16.8 & & Manisa & 100 & 25.0 \\
\hline $11-15$ years & 65 & 16.3 & & Total & 400 & 100.0 \\
\hline $\begin{array}{c}15 \text { years and } \\
\text { over }\end{array}$ & 118 & 29.5 & & $\begin{array}{l}\text { Graduated Department / } \\
\text { Faculty }\end{array}$ & Frequency & Percent \\
\hline Total & 400 & 100.0 & & $\begin{array}{l}\text { Business, Economics, Political } \\
\text { Science. }\end{array}$ & 229 & 57.3 \\
\hline $\begin{array}{l}\text { Working Time } \\
\text { in the City }\end{array}$ & Frequency & Percent & & Tourism & 109 & 27.3 \\
\hline $1-5$ years & 137 & 34.3 & & Science Literature, Education & 42 & 10.5 \\
\hline $6-10$ years & 80 & 20.0 & & $\begin{array}{c}\text { Engineering, Agriculture, Forest, } \\
\text { Law }\end{array}$ & 20 & 4.9 \\
\hline $11-15$ years & 61 & 15.3 & & Total & 400 & 100.0 \\
\hline $\begin{array}{c}15 \text { years and } \\
\text { over }\end{array}$ & 122 & 30.5 & & & & \\
\hline Total & 400 & 100.0 & S & 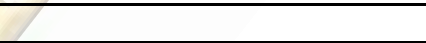 & & \\
\hline
\end{tabular}

When Table 1 is analyzed, the majority of the managers participating in the study are male managers (57\%), when we look at the age group, they are in the middle age group with a rate of approximately $57 \%$ (between $26-45$ ), 88,7\% of the participants are at least high school and university graduates. On the other hand, it has been stated that the managers participating in the research, mostly work in middle-level executive positions (78\%), and they have a middle-income level of $5000 £-6999 £(42 \%)$. On the other hand, the thermal hotel managers who participated in the research generally have a management experience of 1-5 years, considering the city where the managers live, the level of participation in İzmir, Aydin, Denizli and Manisa provinces is close to each other. The thermal hotel managers who participated in the research generally 
work in the city where they live for a minimum five years, and it is seen that most of them do not graduate from any department related to tourism.

\subsection{Findings Related to Explanatory Factor Analysis}

An explanatory factor analysis was conducted based on the data that constitute the perceptions of managers about the competitive factors/levels of the thermal health tourism sector. The analysis carried out in this context is given below.

Table 2. Thermal Health Tourism Sector Explanatory Factor Analysis Results

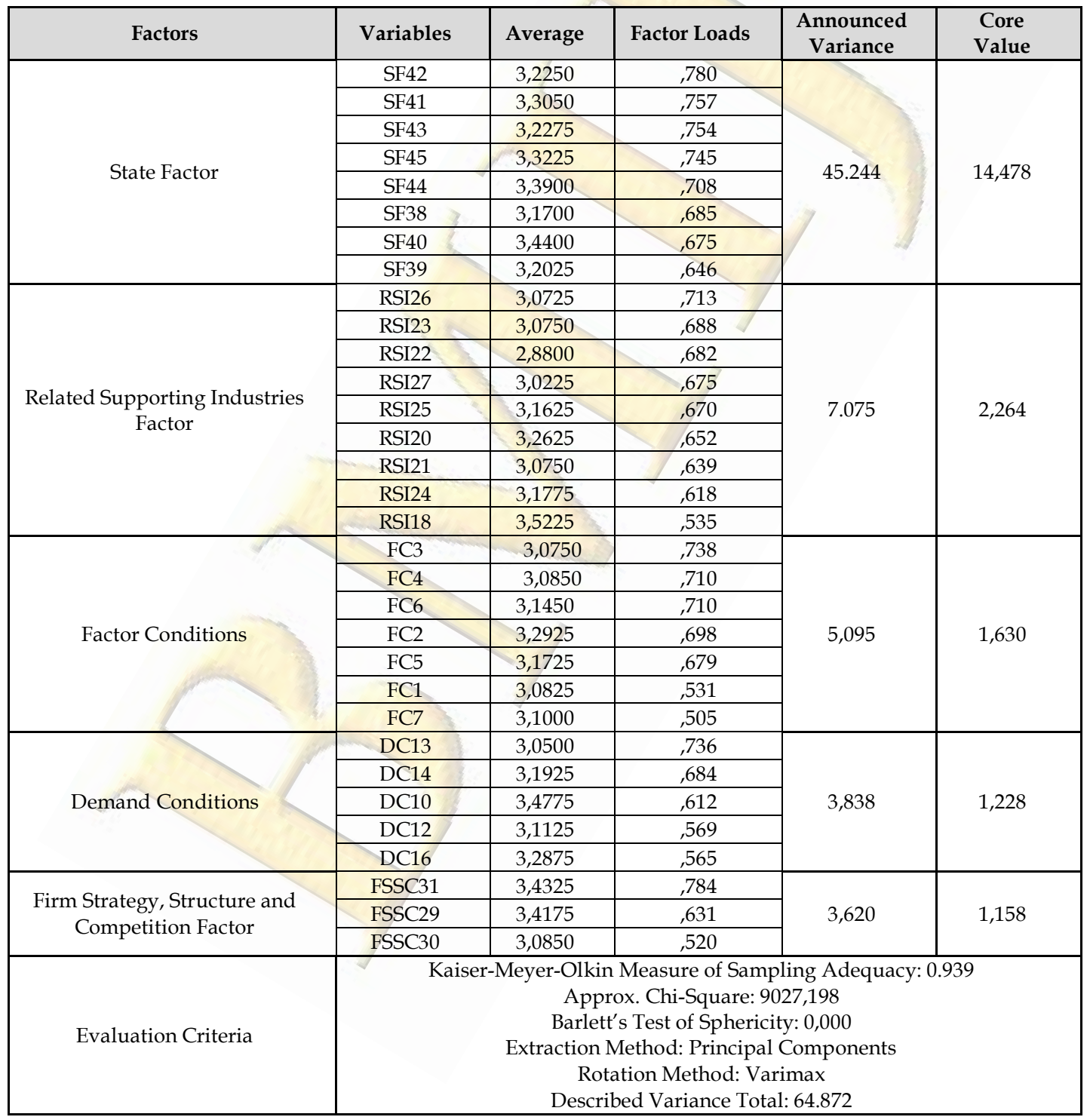

Accordingly, it is seen that the $\mathrm{KMO}$ value of the data analyzed to determine the sub-variables of competitiveness factors within the scope of the thermal health tourism sector and the Bartlett test result are suitable for factor analysis (KMO value 
is 0.939 . Bartlett Test result $\mathrm{p}<0.001)$. The total variance explained by these factors regarding the scale is $64,872 \%$.

\subsection{Descriptive Statistics on Competitiveness Factors}

After the explanatory factor analysis, descriptive statistics about the variables obtained were examined. The averages, standard deviations, reliability coefficients, question numbers and scale levels used for each variable were specified.

Table 3. Descriptive Statistics on Factors

\begin{tabular}{|c|c|c|c|c|c|c|}
\hline \multirow{2}{*}{ Structures } & Factors & Average & $\begin{array}{c}\text { Std. } \\
\text { Deflection }\end{array}$ & $\begin{array}{c}\text { Number of } \\
\text { questions }\end{array}$ & $\begin{array}{c}\text { Reliability } \\
\text { Coefficient }\end{array}$ & $\begin{array}{c}\text { Scale } \\
\text { Level }\end{array}$ \\
\hline & State Factor & 3,285 &, 97761 & 8 & 0,928 & 5 \\
\cline { 2 - 7 } & $\begin{array}{c}\text { Related Supporting } \\
\text { Industries Factor }\end{array}$ & 3,139 &, 90057 & 9 & 0,923 & 5 \\
\cline { 2 - 7 } & Factor Conditions & 3,136 &, 90551 & 7 & 0,891 & 5 \\
\cline { 2 - 7 } $\begin{array}{c}\text { Thermal Health } \\
\text { Tourism } \\
\text { Competitiveness }\end{array}$ & Demand Conditions & 3,224 &, 86803 & 5 & 0,833 & 5 \\
\cline { 2 - 7 } & $\begin{array}{c}\text { Firm Strategy, Structure } \\
\text { and Competition Factor }\end{array}$ & 3,312 &, 86612 & 3 & 0,702 & 5 \\
\hline
\end{tabular}

When the table is analyzed, it is seen that the Firm's Strategy, Structure and Competition Factor (Avg: 3,312) has the highest average in the competitiveness of the thermal health tourism sector. This was followed by the State factor (3.285), Demand Conditions factor (3.224), Related Supporting Industries Factor (3.139) and Factor Conditions (3.136), respectively. After determining the levels of all factors, the competitive position of the sector was determined with the same methodology. At this point, the effect level of the four factors (Related Supporting Industries Factor, Factor Conditions, Demand Conditions and Firm Strategy, Structure and Competition Factor) that are inherent in the model is assumed to be medium level, and the effect level of the external factor is the medium level.

However, the reliability coefficients higher than 0.60 reveal that the scales used in the study are reliable. 


\subsection{Findings on Confirmatory Factor Analysis (CFA)}

In this section, the degree of compliance of the data with the default model was tested by using the AMOS package program and conducting CFA on the scale of thermal health tourism sector competitiveness. It is assumed that the factors (latent variables) in the research model can be explained by the State Factor, Related Supporting Industry Factor, Factor Conditions, Demand Conditions, Firm Strategy Structure and the Competitive Factor and the causal relationships between these factors. The competitiveness of the thermal health tourism sector in the research model was not considered as one-dimensional, and the model was created by assuming that they were explained by the sub-latent variables of each Confirmatory factor analysis was performed to test the validity of the scale used, and it was observed that the scale's adaptation coefficients were provided. Since only a few of the compliance values produced by the measurement model created for the test of the validity of the thermal health tourism sector competitiveness analysis scale are not within the acceptable limits, the modifications have been made as proposed by the program. Figure 2 from thermal health tourism sector competitiveness analysis regarding confirmatory factor analysis and goodness of fit values are shown. 


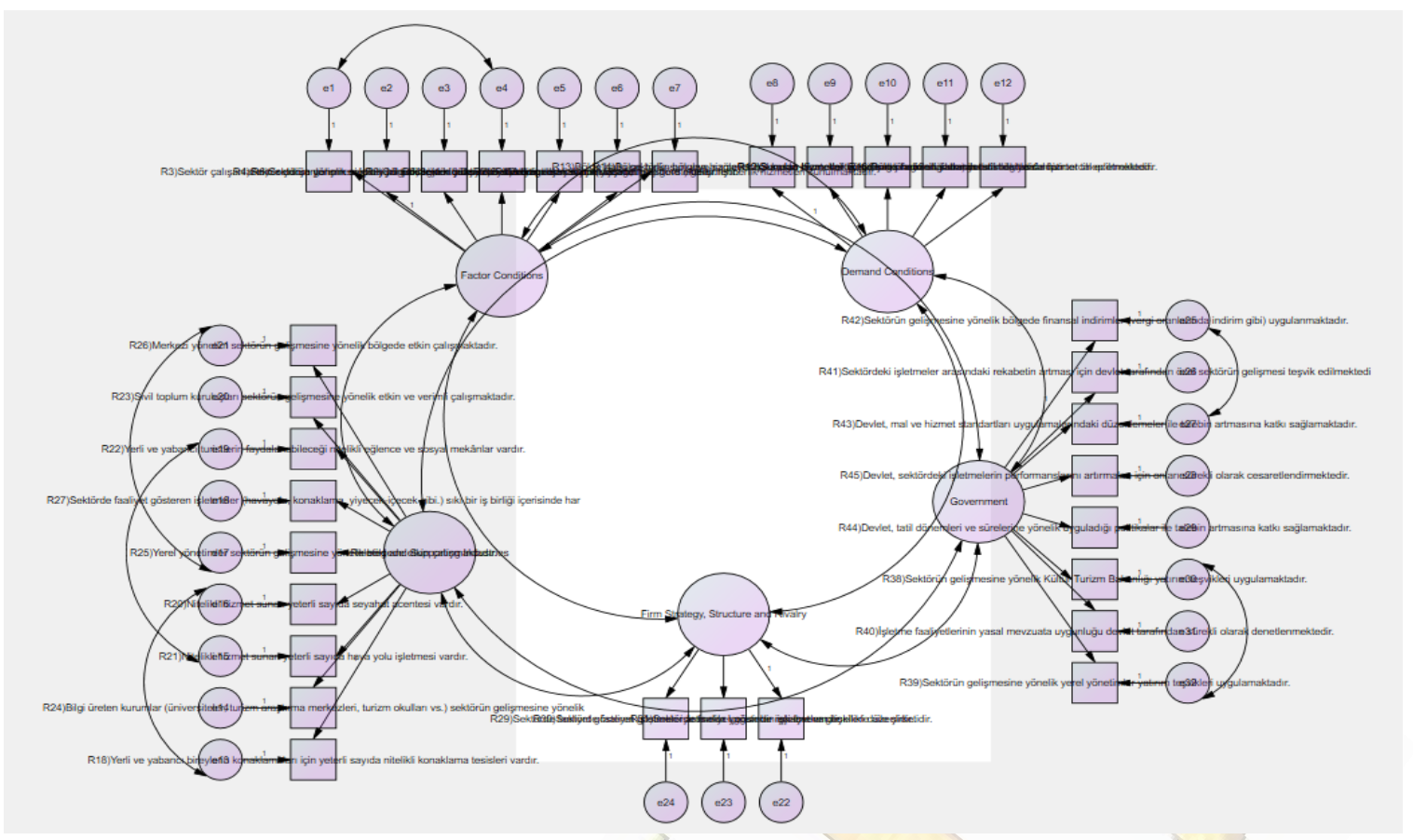

[(X²/df: 2.708; GFI: 0.75; NFI: 0.75; CFI: 0.82; RMSEA: 0.064; Model AIC = 4082,190; Independence AIC = 15344,540; Model CAIC = 4712,221; Independence CAIC = 15621,754; ECVI: 9,743; ECVI Independence Model = 36, 622)]

Figure 2. Thermal Health Tourism Sector Competitiveness Analysis Research Model (Measurement Model) and Goodness of Fit Results

Confirmatory Factor Analysis (CFA) was applied to the corrected measurement model to reveal to what extent the observed variables can explain the latent variables. In addition, the explained variance and reliability of the calculated factors determining the validity and reliability of the measurement model are given in Table 4. 
Table 4. CFA Results on Improved Measurement Model

\begin{tabular}{|c|c|c|c|c|c|}
\hline $\begin{array}{l}\text { Implicit } \\
\text { Variables }\end{array}$ & Observed Variables & $\begin{array}{c}\text { Standardized } \\
\text { Regression } \\
\text { Coefficients }\end{array}$ & $\begin{array}{l}\text { Standard } \\
\text { error }\end{array}$ & $\begin{array}{c}\text { T } \\
\text { Value }\end{array}$ & $\mathbf{P}$ \\
\hline \multirow{7}{*}{$\begin{array}{c}\text { FACTOR } \\
\text { CONDITIONS }\end{array}$} & FAC.CON. & ,743 & & 14,305 & $* * *$ \\
\hline & FAC.CON. & ,743 & ,067 & & \\
\hline & FAC.CON. & ,774 & 071 & 16,106 & $* * *$ \\
\hline & FAC.CON. & ,692 & ,055 & 11,548 & $* * *$ \\
\hline & FAC.CON. & ,730 & ,069 & 14,466 & $* * *$ \\
\hline & FAC.CON. & ,706 & ,073 & 13,168 & $* * *$ \\
\hline & FAC.CON. & ,726 & , 077 & & \\
\hline \multirow{5}{*}{$\begin{array}{c}\text { DEMAND } \\
\text { CONDITIONS }\end{array}$} & DEM. CON. & ,764 & & 12,512 & $* * *$ \\
\hline & DEM. CON. & 801 & ,065 & 10,903 & $* * *$ \\
\hline & DEM. CON. & ,591 & ,063 & 13,518 & $* * *$ \\
\hline & DEM. CON. & ,726 & ,065 & 12,174 & $* * *$ \\
\hline & DEM. CON. &, 667 & , 070 & 12,693 & $* * *$ \\
\hline \multirow{9}{*}{$\begin{array}{c}\text { RELATED } \\
\text { SUPPORTING } \\
\text { INDUSTRIES }\end{array}$} & REL.SUPP.INDUST.. &, 592 & 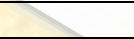 & 11,906 & $* * *$ \\
\hline & REL.SUPP.INDUST.. & 818 & 104 & 12,549 & $* * *$ \\
\hline & REL.SUPP.INDUST.. & 667 & 111 & 12,153 & $* * *$ \\
\hline & REL.SUPP.INDUST.. & 673 & 083 & & \\
\hline & REL.SUPP.INDUST.. & ,784 & 103 & 10,022 & $* * *$ \\
\hline & REL.SUPP.INDUST.. & 837 & 113 & 8,826 & $* * *$ \\
\hline & REL.SUPP.INDUST.. &, 757 & 113 & & \\
\hline & REL.SUPP.INDUST.. & 821 & 105 & 17,924 & $* * *$ \\
\hline & REL.SUPP.INDUST.. & 782 & ,109 & 23,002 & $* * *$ \\
\hline \multirow{3}{*}{$\begin{array}{c}\text { FIRM } \\
\text { STRATEGY } \\
\text { AND } \\
\text { COMPETITION } \\
\text { STRUCTURE }\end{array}$} & FIRM ST.COM. STRUC & ,564 & 7 & 15,622 & $* * *$ \\
\hline & FIRM ST.COM. STRUC & ,778 & 149 & 16,685 & $* * *$ \\
\hline & FIRM ST.COM. STRUC & 605 & ,134 & 15,639 & $* * *$ \\
\hline \multirow{8}{*}{ STATE } & STATE & ,775 & & 16,278 & $* * *$ \\
\hline & STATE & 832 & 057 & 15,874 & $* * *$ \\
\hline & STATE & 845 & , 046 & 14,305 & $* * *$ \\
\hline & STATE & 742 & ,067 & & \\
\hline & STATE & ,784 & ,060 & 16,106 & $* * *$ \\
\hline & STATE & ,744 & ,064 & 11,548 & $* * *$ \\
\hline & STATE & ,768 & ,063 & 14,466 & $* * *$ \\
\hline & STATE & ,753 & 061 & 13,168 & $* * *$ \\
\hline
\end{tabular}

When the CFA results presented in Table 4 are examined, standardized regression coefficients, $t$ values $(t>1.96)$, $p$ values $(p<0.01)$ and model fit goodness indexes of the observed variables show that the model is at the acceptable fit level. Table 5 also shows the well-being fit index values accepted in the literature and the values obtained after the analysis. 
Table 5. Measurement Model Fit Goodness Indices

\begin{tabular}{|c|c|c|c|}
\hline $\begin{array}{c}\text { General Model } \\
\text { Fit }\end{array}$ & Good Fit & $\begin{array}{c}\text { Acceptable } \\
\text { Compliance }\end{array}$ & $\begin{array}{c}\text { Compliance Values } \\
\text { Obtained }\end{array}$ \\
\hline $\boldsymbol{x}^{2} /$ sd & $\leq 3$ & $\leq 5$ & 3.324 \\
\hline RMSEA & $\leq 0.05$ & $\leq 0.08$ & 0.076 \\
\hline NFU & $\geq 0.95$ & $\geq 0.90$ & 0.84 \\
\hline CFU & $\geq 0.97$ & $\geq 0.95$ & 0.89 \\
\hline IFI & $\geq 0.95$ & $0.94-0.90$ & 0.89 \\
\hline PGFI & Close to 1 & $\begin{array}{c}\text { The lower limit } \\
\text { value is } 0.50\end{array}$ & 0.69 \\
\hline GFI & $\geq 0.90$ & $0.89-0.85$ & 0.82 \\
\hline
\end{tabular}

As can be seen in Table 5, the results show that the proposed research model is generally at the acceptable fit level ( $x^{2} / \mathrm{sd}$, RMSEA, PGFI).

\section{DISCUSSION AND CONCLUSION}

In the research, the thermal health tourism sector competitiveness was analyzed only by using ME Porter's diamond model scale. For this reason, different scales measuring the sector competitiveness can be used in the studies to be carried out.

On the other hand, the study includes the results of the analysis of the thermal facility managers in the provinces of the South Aegean Thermal Tourism Development Region (İzmir, Aydın, Denizli and Manisa). Therefore, it cannot be generalized for the whole country or world thermal health tourism sector or different sectors.

The results of the research are located in the South Aegean Thermal Tourism Development Region (İzmir-Manisa-Aydin-Denizli), which is formed according to the stratified (clustering) sampling method within the scope of 2007-2023 Thermal Tourism Master Action Plan of the Ministry of Culture and Tourism of Turkey. It reflects the perspectives of the upper and middle-level managers of health tourism enterprises.

It can be said that while the majority of the managers who participated in the research are male managers $(57 \%)$, in the middle age group with a rate of approximately 57\% (between 26-45), and are mostly at least high school and university graduates $(88,7 \%)$. On the other hand, it has been stated that the managers participating in the research mostly work in middle-level executive positions $(78 \%)$, and they have a middle-income level of $5000 £-6999 £(42 \%)$. On the other hand, the 
thermal hotel managers who participated in the research generally have a management experience of 1-5 years, considering the city where the managers live, the level of participation in İzmir, Aydin, Denizli and Manisa provinces is close to each other. The thermal hotel managers who participated in the research generally work in the city where they live for a minimum five years, and it was seen that most of them did not graduate from any department related to tourism.

The competitiveness level of the Thermal Health Tourism Sector of the South Aegean Thermal Tourism Development Region has been determined at the medium level as a result of the analysis made with the diamond model. This result was achieved by taking into account the four main variables examined and the level of state contribution to the sector's competitiveness.

According to the results of the factor analysis, one of the experimental analysis methods; the perceptions of managers about the competitive factors of the thermal health tourism sector are gathered in 5 different dimensions. Considering the variance and eigenvalues explained within these dimensions, the dimension that best represents the competitiveness in the sector is the "state factor" dimension. This is followed by in order; "Relevant and supportive industries", "factor conditions", "demand conditions" and "firm strategy structure and competition" dimensions.

Confirmatory factor analyses were performed; the thermal health tourism sector has been found to have an acceptable fit index of competitiveness factors it was also determined that the reliability levels of the scales were high in the reliability analysis for all variables. According to the confirmatory factor analysis results; the competitive factors of the thermal health tourism sector are gathered under five dimensions. These are; The State Factor, Related Supporting Industry Factor, Factor Conditions, Demand Conditions and Firm Strategy Structure and Competition Factor.

When looking at similar studies in the literature; the competition conditions of the tourism sector of Antalya province were evaluated within the framework of Porter's five power analysis and the factors affecting the structure of the current and future competition level were determined, and the reasons and results of the deficiencies in the competitive strategies of the enterprises were determined (Keklik 
Okul, 2019). Besides, the thermal tourism potential of Kozaklı (Nevşehir) district centre and the thoughts of tourists on thermal tourism were evaluated, and it was concluded that thermal tourism enterprises should provide accurate information to customers in promotional tools such as advertising brochures and catalogues and activities that would strengthen the image of the enterprise (Çetin, 2011). In another study, Bulu and Eraslan (2008) used Porter's diamond model to analyze the international competitiveness of the tourism sector in the province of Bolu, and it was determined that the international competitiveness of the tourism sector in Bolu province was at medium level.

In the study conducted to analyze the competitiveness of tourism in Middle Eastern countries using the travel and tourism competitiveness index published in the World Economic Forum report; Although Egypt, Iran, Kuwait, Lebanon and Yemen improved their situation compared to 2015; it has shown that they are unable to develop their competitiveness compared to other Middle Eastern countries and are included in the group of countries with low tourism competitiveness (Nazmfar et al., 2019). In another study conducted to determine the competitiveness characteristics in small and medium destinations and the causal relationships between tourism destination competitiveness, it was seen that managerial capabilities and service quality and policies aimed at promoting local empowerment were the main determinants of the competitiveness of the Italian small and medium-sized destinations (Goffi and Cucculelli, 2018).

In the research, the competitiveness level of the thermal health tourism sector was analyzed using Michael Porter's diamond model scale. For this reason, Various scales that measure the competitiveness of the thermal health tourism sector can be used in future studies. Additionally, the relationship between the competitiveness factors of the thermal health tourism sector was examined within the scope of the research. In order to enrich the literature, it would be imperative to look at the relationships between other similar variables and to produce model studies within the framework of exploratory analysis and confirmatory model in future studies. 
In addition to this, the research includes the results of the analysis regarding the thoughts of the thermal managers in İzmir, Manisa, Aydın and Denizli provinces. Therefore, it is hard to generalizing the results of this study worldwide thermal health tourism sector as well as for different sectors. Taking advantage of the comprehensive framework drawn in the researches and the results obtained as a result of the research, a scale can be developed to measure the competitiveness levels and factors of competitiveness or different countries.

As a result of the research, it is understood that emphasis should be placed on improving and developing competitiveness factors in sectoral terms. Due to the various factors affecting competitiveness, it is also important to study under which factor or factors. Based on this study conducted in İzmir, Manisa, Aydın and Denizli provinces, it is suggested that the perception of competitiveness factors of the thermal health tourism sector should be developed and strengthened in order to increase competitiveness in the sectoral sense. As emphasized in the literature, all existing elements must be mobilized to meet the needs of the target audience in order to create a successful brand image (Sartori et al., 2012: 327).

Similarly, it is predicted that the attractiveness and potential as a suitable region and business environment can be supported by investment incentives of the local government of the promotion of private-sector by the state (Minghetti and Montaguti, 2010: 172). Therefore, it has been observed that these competitiveness factors, which contribute to the image of the destination, are considered as a strategic tool in the process of destination branding (Seisdedos and Vaggione, 2005: 1). Therefore, improving and developing competitiveness factors in sectors where the destination is competitive can strengthen the competitiveness level of the destination.

On the other hand, in an industry where a destination is competitive, the presence of relevant and supportive industries within an adequate support network strengthens the destination's level of competitiveness because the targeted success in branding a region depends on the existence of effective communication between the stakeholders operating in the sector and the quality of the services provided to the stakeholders (Hankinson, 2004: 116). 
Based on the thoughts of thermal health tourism sector managers; it is recommended to increase the knowledge level of the sector employees towards the sector besides improving the infrastructure opportunities for the sector and the sectoral education level of the sector employees. Similarly, it has been suggested that it is necessary to ensure that the local people regularly follow international markets and that the people of the region have sufficient awareness about the socio-economic benefits the sector that would provide to the region. The presence of a high expectation local demand also puts pressure on the companies in the sector to develop more innovative products (DTM, 2009: 11). Therefore, the presence of domestic demand and qualified local demand in sectors where the destination is competitive strengthens the competitiveness level of the destination. Additionally, it is suggested that the number of entertainment quality and social venues that tourists could benefit from in the specified cities should be increased. Moreover, tight coordination should be ensured among the enterprises operating in the sector, and the central administration should work effectively for the development of the sector. Finally, it was suggested that the central government should implement investment incentives for the development of the sector. 


\section{REFERENCES}

Albayrak, A. (2013), Alternatif Tourism, Detay Publishing House: Ankara.

Alsaç, F. (2010), Clustering Approach as a Tool for Regional Development and Clustering Support Model Proposal for Turkey, Planning Expertise Thesis, DPT, Ankara.

Bulu, M. and Eraslan, İ.H. (2008), International Competitiveness Analysis of Tourism Sector in Bolu Province. Journal of Travel and Hotel Management, 5(1), Retrieved from https://dergipark.org.tr/tr/pub/soid/issue/11378/135963

Çetin, T. (2011), Kozaklı (Nevşehir) Hot Springs in terms of Thermal Tourism Potential. Turkish Studies International Periodical For the Languages, Literature and History of Turkish or Turkic, 6(1), 899-924.

Çetin, T. (2011), Nevşehir (Kozakl1) Hot Springs in Terms of Thermal Tourism Potential. Turkish Studies - International Periodical for the Languages, terature and History of Turkish or Turkic, 6(1),

Cho, D.S. (1999), From National Competitiveness to Bloc and Global Competitiveness, Competitiveness Review, 8(1), 27-34.

Dear, E. (2008), Clustering Approach and Turkey, magnifying Journal, Ankara Chamber of Industry Publications January-February 2008.

Donald, D.J. (1993), Porter's Diamond and Exchange Rates, Management International Review; Second Quarter, 33(2).

DTM (2009), Development of a Clustering Policy for Turkey. Clustering Approach in Organized Industrial Zones, OSTIM Example and Roadmap for Ankara Construction and Construction Machinery Work Cluster. Ankara: DTM Publications.

Erdinç, T. (1991), In Afyonkarahisar thermal tourism potential, Tourism Yearbook 1991 Publication of the Development Bank of Turkey, Ankara.

Gawell, K. and Greenberg, G. (2007), 2007 Interim Report, Update on World Geothermal Development, Geothermal Association, May 1 , http://www.geoenergy.org/publications/reports/GEA\%20World\%20Update\%202007.pdf(Accession : 20.01.2020).

Giritlioğlu, İ. (2012), Service Quality Expectations and Perceptions of Employees and Customers in Food and Beverage Departments: A Research in Thermal Hotels. Unpublished Doctoral Thesis, Balikesir University Institute of Social Sciences, Balikesir. 
Goffi, G. and Cucculelli, M. (2018), Explaining tourism competitiveness in small and medium destinations: the Italian case. Current Issues in Tourism, 22(17), https://doi.org/10.1080/13683500.2017.1421620

Grant, R.M. (1991), Porter's' Competitive Advantage of Nations': An Assessment. Strategic Management Journal, 12(7), 535-548.

Hankinson, G. (2004), The Brand Images of Tourism Destinations: A Study of the Saliency of Organic Images, Journal of Brand Management, 13(1).

Hodgetts, R.M. (1993), M. Porter's Diamond Framework in A Mexican Context, Management International Review, 33(2), 41-54.

İlban, M.O., Köroğlu, A. and Bozok, D. (2008), Destination Image for Tourists Traveling for Thermal Tourism: The Example of Gönen. Istanbul Commerce University Journal of Social Sciences, 7(13), 105129.

Karagülle, M.Z. and Doğan, B.M. (2002), Guide Hot Springs Spa Medicine and Turkey, Istanbul Nobel Bookstores.

Karamustafa, K., Ulama, Ş. and Erbaş, E. (2009), Competitiveness Analysis of Kozaklı District in Terms of Thermal Tourism, 10th National Tourism Congress, School of Tourism and Hotel Management, 2124 October 2009, Mersin University, 495-514, Mersin.

Keklik Okul, F. (2019), Investigation of Antalya Tourism Sector within the Frame of Porter's 5 Power Analysis. International Social Sciences Studies Journal, 5 (44), 5163-5176.

Lall, S. (2001), Competitiveness Indices and Developing Countries: An Economic Evaluation of the Global Competitiveness Report, World Development, 29 (9).

Minghetti, V. and Montaguti, F. (2010), Cities to Play: Outlining Competitive Profiles for European Cities, (Edited by: Josef A. Mazanec and Karl W. Wöber). Analyzing International City Tourism (Second Edition). Netherland: Springer Wien New York, 171-190.

Ministry of Health, Health Tourism Handbook, Ankara, 2012.

Momeni, K., Janati, A., Imani, A., Khodayari-Zarnaq, R. and Arab-Zozani, M. (2017), An analysis of competitive situation medical tourism industry: a case study in northwest Iran. Bali Medical Journal, 6 (2), 279-288. DOI: 10.15562 / bmj.v6i2.529 
Nazmfar, H., Eshghei, A., Alavi, S. and Pourmoradian, S. (2019), Analysis of travel and tourism competitiveness index in middle-east countries. Asia Pacific Journal of Tourism Research, 24(6), 501513. https://doi.org/10.1080/10941665.2019.1590428

Öz, Ö. (2002), Assessing Porter's framework for national advantage: the case of Turkey, Journal of Business Research, 55, 509-515.

Porter, E.M. (1998), The Competitive Advantages of Nations, New Edition, Palgrave.

Porter, M. (1990), The Competitive Advantage of Nations, New York: The Free Press.

Rosensweig, J.A. (2007), Medical tourism - health care in the global economy.

Sartori, A., Mottironi, C. and Corigliano, M. A. (2012). Tourist Destination Brand Equity and Internal Stakeholders: An Empirical Research. Journal of Vacation Marketing, 18(4), 327-340.

Seisdedos, G. and Vaggione, P. (2005). The City Branding Processes: The Case of Madrid. 41st ISoCaRP Congress, 1-10.

Şengül, H., and Bulut, A. (2019). Health Tourism Thermal Tourism in Turkey in the Framework; A Swot Analysis Study. ESTÜDAM Public Health Journal, 4 (1), 55-70.

Smith, A. (1776), Wealth of Nations, Translation: Ayşe Yunus and Mehmet Bakırc1, Alan Publishing.

Timur, B. (2015). Examination of Relationships Between Service Quality in Thermal Tourism, Perceived Destination Image and Re-Visit Intention, Eskişehir Osmangazi University, Institute of Social Sciences, Tourism Management Department, Tourism Management Science Branch, - Master Thesis, Eskişehir.

Upadhyay, P. (2011), Comparative and Competitive Advantages of Globalized India as a Medical Tourism Destination, International Journal of Engineering and Management Sciences, 2(1), 26-34.

Webster, D. and Muller, L. (2000), Urban Competitiveness Assessment in Developing Country Urban Regions: The Road Forward, The World Bank, Washington DC., July.

Wu, C.R., Lin, C.T. and Chen, H.C. (2007), Optimal Selection Of Location For Taiwanese Hospitals To Ensure A Competitive Advantage By Using The Analytic Hierarchy Process And Sensitivity Analysis, Building and Environment, 42, 1431-1444. 


\section{ETHICS COMMITTEE APPROVAL}

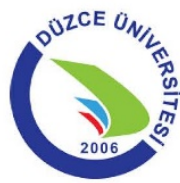

\author{
T.C. \\ DÜZCE ÜNIVERSITESI REKTÖRLÜĞÜ \\ Genel Sekreterlik \\ Etik Kurul Bürosu
}

Say1 :52408282/640/

Konu :Etik Kurul Kararı

IŞLETME FAKÜLTESİ DEKANLIĞINA

İlgi : : : 17/02/2020 tarihli, BILAA sayıl1 ve DILEKÇE konulu yazı

Fakülteniz Sağlık Yönetimi Bölümü Öğretim Elemanı Dr. Öğr. Üyesi Fuat YALMAN'ın Kurulumuza yapmış olduğu 17.02.2020 tarihli başvurusu üzerine dilekçe ekinde yer alan anketler değerlendirilmiş olup yapılan değerlendirme sonucunda Kurulumuzca alınan 20.02.2020 tarihli ve 2020/28 - 2020/29 Karar sayılı kararlar adı geçene tebliğ edilmek üzere ekte gönderilmektedir.

Bilgilerinizi ve gereğini rica ederim.

Prof.Dr. İlhan GENÇ

Bilimsel Araştırma ve Yayın Etik Kurulu

Başkanı

EKLER :

1- 20.02.2020 tarihli ve 2020/28 Karar sayılı karar.

2- 20.02.2020 tarihli ve 2020/29 Karar sayılı karar.

https://ebvs.duzce.edu.tr/envision-Dogrula/BelgeDogrulama.aspx

Konuralp Yerleşkesi Merkez / DÜZCE $81620 \quad$ BARKOD NO: *BENU5LPKR*
Ayrıntllı bilgi için irtibat: Ahmet SSENGÜL

Tel: : (0380) $5421110 \quad$ Faks: (0380) 5421103

Faks: (0380) 5421103 
T.C.

DÜZCE ÜNIVERSITESI

BİLIMSEL ARASTTIRMA VE YAYIN ETIK KURULU KARARLARI

\section{TOPLANTI SAYISI}

3
KARAR SAYISI

$2020 / 28$
KARAR TARIHI

20.02 .2020

\section{KARAR NO: 2020/28}

Düzce Üniversitesi İşletme Fakültesi Sağlık Yönetimi Bölümü Öğretim Elemanı Dr. Öğr. Üyesi Fuat Yalman'ın "Termal Amaçı Seyahat Eden Bireylerin İmaj ve Hizmet Kalitesi Algıları ile Tekrar Tercih Etme Davranışları Arasındaki İlişkinin Belirlenmesi: Bursa Kaplıcaları Örneği” başlıklı çalışması kapsamında uygulamak istediği anket ölçeğinin etik olarak uygun olduğuna,

Oy birliği ile karar verildi.

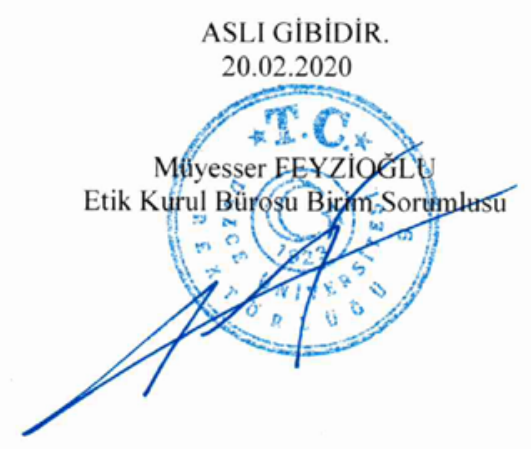


T.C.

DÜZCE ÜNIVERSITESI

BILLIMSEL ARAŞTIRMA VE YAYIN ETIKK KURULU KARARLARI

TOPLANTI SAYISI
KARAR SAYISI

$2020 / 29$
KARAR TARİHI

20.02 .2020

\section{KARAR NO: 2020/29}

Düzce Üniversitesi İşletme Fakültesi Sağlık Yönetimi Bölümü Öğretim Elemanı Dr. Öğr. Üyesi Fuat Yalman'ın “Güney Ege Termal Turizm Gelişim Bölgesinin Termal Sağlık Turizmi Sektörünün Rekabetçilik Düzeyinin Tespit Edilmesi " başlıklı çalışması kapsamında uygulamak istediği anket ölçeğinin etik olarak uygun olduğuna,

Oy birliği ile karar verildi.

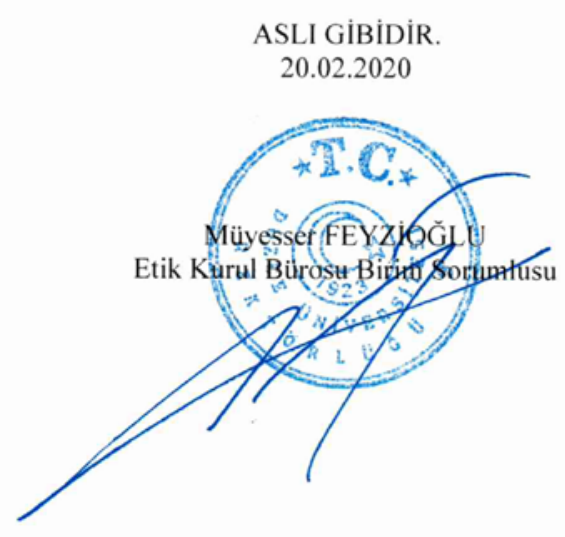

